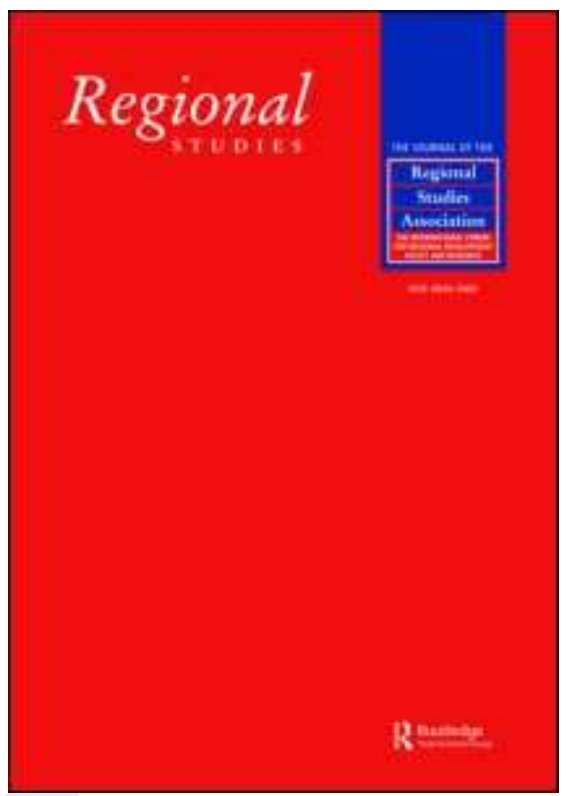

\title{
Regional Policy and University Knowledge Transfer: Perspectives from Devolved Regions in the UK
}

\begin{tabular}{|r|l|}
\hline Journal: & Regional Studies \\
\hline Manuscript ID: & CRES-2009-0223.R3 \\
\hline Manuscript Type: & Policy Debates \\
\hline JEL codes: & $\begin{array}{l}\text { O3 - Technological ChangelResearch and Development < O - } \\
\text { Government Policy < I2 - Education < I - Health, Education, and } \\
\text { Welfare, O - Economic Development, Technological Change, and } \\
\text { Growth, R - Urban, Rural, and Regional Economics }\end{array}$ \\
\hline Keywords: & $\begin{array}{l}\text { devolution, knowledge transfer, knowledge commercialization, } \\
\text { universities, Scotland, Wales }\end{array}$ \\
\hline
\end{tabular}

\section{SCHOLARONE" Manuscripts}




\title{
Regional Policy and University Knowledge Transfer: Perspectives from Devolved Regions in the UK
}

\author{
Robert Huggins \\ Centre for International Competitiveness \\ Cardiff School of Management \\ University of Wales Institute, Cardiff \\ Western Avenue, Cardiff, CF5 2YB, UK \\ Tel: +44 (0) 2920416470 \\ E-mail: rhuggins@uwic.ac.uk \\ Fumi Kitagawa \\ Manchester Enterprise Centre \\ Manchester Business School \\ University of Manchester \\ Tel: +44 (0)1613068433 \\ Email: fumi.kitagawa@mbs.ac.uk
}

(Received July 2009: in revised form January 2011) 


\begin{abstract}
This paper constitutes a policy analysis of university knowledge transfer-related initiatives in the devolved regions of Scotland and Wales. Both regions are seeking to develop science-based innovation strategies in which universities play a central role. Scotland appears fairly well advanced in this regard, whilst in Wales the establishment of regional networks linking actors has been more problematic to establish. It is concluded that whilst devolution has facilitated significant supply-side intervention, future intervention will require a stimulus in the demand for university knowledge. Furthermore, policies will be required to pay more attention to the global environment within which knowledge flows.
\end{abstract}

Key words: devolution; knowledge transfer; knowledge commercialization; universities; Scotland; Wales.

\title{
Introduction
}

Recent political and academic discourse concerning devolution has tended to stress the economic advantages of the transfer of power from national to sub-national institutions, characterized as the 'economic dividend' of devolution (Rodríguez-Pose and Gill, 2005). In the UK context, devolution in Scotland and Wales since 1997, resulting in the establishment of the Scottish Parliament and the National Assembly of Wales in 1999, has introduced a partially devolved system of higher education, science and research. Although the divergence of higher education policies predates devolution in the UK, this has become more marked over the last decade (Universities UK, 2008). Nevertheless, it is notable that whilst some powers and responsibilities related to science and innovation policy are devolved to regional governments, national (and transnational) governments still tend to retain a significant influence.

National and regional debates on the role of regional science and innovation systems, and the role of universities and higher education institutions (HEIs), are intrinsically linked to these wider issues over governance and devolution, which constitute a multilevel governance (MLG) structure of science and innovation policy (Perry and May, 2007). The institutional multi-level dimensions of devolution processes conditioned by different forms of 'economic governance' (Jones et al., 2005; Cooke and Clifton, 2005; Goodwin et al., 2005) and knowledge transfer and exchange between different actors constituting innovation systems warrants further investigation and analysis. Knowledge transfer and knowledge exchange are seen as priority areas for research and innovation policy development (European Commission, 2007; ESRC, 2009). The effects of regional devolution on higher education, research funding and the 
management of knowledge transfer are a growing area of policy concern (Universities UK, 2008). This paper focuses on Scotland and Wales, both of which have developed distinctive institutional mechanisms as part of the political devolution process.

The focus of the paper is primarily a policy level analysis of university knowledge transfer activities and initiatives, and the extent to which these have been accelerated by devolution. Scotland and Wales clearly have different histories and different processes of devolution, and it is not the primary purpose of this paper to compare these directly, but to use devolution as the backdrop for better understanding how regional policy in relatively autonomous political settings can play a role in shaping distinctive forms of intervention. The paper aims to highlight the different structures and institutional mechanisms through which knowledge capabilities are constructed, and identify different patterns of interactions through which innovation systems are emerging.

The paper seeks to address the following broad empirical questions: (1) To what extent have policies and strategies for innovation and science, knowledge transfer from HEIs in Scotland and Wales evolved post-devolution? (2) What are the main initiatives, in terms of public policy programmes and resources, made available to catalyze university knowledge transfer performance? and (3) In what ways have processes of devolution impacted on the development of innovation systems in Scotland and Wales respectively? By reviewing policy discourses and the development of policy initiatives over the last decade, this paper critically examines how empowered regional policy should and/or could facilitate more effective regional innovation systems and also impact on the development of the knowledge transfer performance of HEIs. Attention is drawn to the development of regional science and innovation policies, and the strategies implemented by the two case study regions in terms of mobilizing regional innovation and knowledge capabilities, and supporting universities to effectively transfer their knowledge.

The paper is structured as follows. The second section provides a review of the literature and presents our conceptual framework concerning 'multi-level governance relations' of science and innovation policy associated within a regionally devolved context. The sections following the literature present an analysis of developments in 
Scotland and Wales largely based on the key concepts and issues raised by the study, namely: governance and regional devolution; regional innovation and science policy; the characteristics of the university sector and university knowledge transfer policies; the evolution of policy; the role of complementary innovation infrastructure; and the relative 'performance' of universities in terms of knowledge transfer. The final section discusses the findings from a theoretical perspective by critically examining the university knowledge transfer in the regional policy framework. The paper concludes with issues for future research concerning the development of regional innovation systems and key policy implications.

\section{Governance and the Regionalization of Innovation and Science Policy}

In recent years, both policy and academic attention have been drawn to the processes of globalization, the rise of knowledge-based economy, and the 'hollowing out' of the state (Jessop, 2004), with the growing significance of city-regions (Scott, 2001; Turok, 2008) and of locality and spatial proximity in economic development and innovation processes (Huggins and Izushi, 2007). Science policy has not traditionally been considered a 'legitimate policy target of devolution and regionalization processes', whereas the division of responsibility over innovation and technology policy seems to be more complex (Perry and May, 2007, p1042). Although some powers and responsibilities related to science and innovation policy are devolved to regional governments, national (and transnational) governments still tend to retain significant influence, especially with regard to the social shaping of the 'national science base' (Pavitt, 1998). The power structures in which these institutions interact affects how innovation systems operate regionally and nationally in the globalizing knowledge economy (Kitagawa, 2007).

In many regions, universities are viewed as the core of the knowledge base and at the heart of the knowledge economy, acting as key elements of innovation systems, supporting science and innovation-based regional growth (Huggins et al., 2008). Consequently, university-industry interactions often seem to have been 'subsumed into broader analytical and normative policy debates' concerning innovation and local and regional development (Srinivas and Viljamaa, 2008). To be effective, policy initiatives to promote regional innovation require detailed knowledge of the locality and the engagement of a range of regional and non-regional actors. However, as 
Chatterton and Goddard (2000) argue, the issue of territoriality is not so straightforward for universities. To begin with, three spatial levels of activities can be distinguished in the higher education landscapes, namely, international, national and regional/local. These three levels are not exclusive but complement each other.

Today universities virtually always hope to be part of 'an international knowledge network', but increasingly even the most traditional and prestigious ones look to their region and locality for support, and also claim credit for adding to the area's economic and social strength (Lawton Smith, 2007; Kitson et al., 2009; Huggins et al., 2008). For example, universities have an important role to play in preserving local jobs, diversifying the local economy and attracting inward investors. Universities as knowledge infrastructures affect the knowledge flows between themselves and other institutions and actors at different geographical scales. The internationalization of university-industry relations has been rapidly developing, and as Etzkowitz (2002) argues 'the triple helix' interaction between university-industry-government is a move towards a new global model for the management of knowledge and technology, where an internationalization strategy emerges within domestic policy structures. In this context, one could argue that universities may fulfill a useful role in blurring the line between these different levels by 'regionalizing' world class and small high technology firm relationships, and by making knowledge available to actors whose innovative locus is much more regional in character.

Nevertheless, in order for regions to operate through global network nodes, and as part of a global-regional innovation system, communities surrounding universities need to have the capability to absorb and exploit the science, innovation, and the technologies generated by the universities (Florida, 1999). There are often considerable differences in the capability of universities to effectively transfer their knowledge, and of regional businesses to effectively absorb such knowledge (Huggins, 2008). In general, firms and regions are better placed to innovate if they have built up 'the right resources and capabilities' (Driver and Oughton, 2008). This process is also conditioned by structural, institutional and social factors that interact within regions (Boucher et al 2003), and the articulation of regional policies and the ability of universities to effectively mobilize stakeholders for innovation (Uyarra, 2010). Therefore, any regional innovation system development needs to be seen as 
part of the 'co-evolution' process between 'global and national structures' and 'global-national-regional interactions' (Sotarauta and Kautonen, 2007). Whilst recognizing the multi-spatial context within which innovation actors are embedded, in this paper we seek to concentrate on how policy influences the regional segment of interaction between innovation actors, especially universities. In other words, and as Figure 1 presents, we seek to examine the extent to which regional science and innovation policies in devolved regions have embraced 'regional' university knowledge transfer policies as means of building their regional innovation systems.

Figure 1 About Here

In general, although there is recognition that universities are potentially key players in achieving economic transformation, the underlying policy perspective is that they are often under-utilized. In the field of higher education, UK policy over the last decade has witnessed a growing alignment between the 'third stream' activities of universities and regional economic development (NCIHE, 1997; Charles, 2003; Goddard and Chatterton, 1999). Indeed, recent years have witnessed a plethora of policy interventions highlighting both national and regional government commitment to science and technology, and the importance of the higher education sector in achieving a step change in the UK's innovation performance by facilitating the growth of the knowledge economy. The last decade has witnessed the transfer and commercialization of university-generated knowledge taking a stronger role within government policies at a number of levels (Lambert, 2003; Sainsbury, 2007; Wellings, 2008; Kitson et al. 2009).

It has been pointed out, however, that there is a still a lack of understanding of how to create effective impacts through knowledge transfer from universities, and the role of regions as part of these processes (Porter and Ketels, 2003). Also, there has been little systematic analysis of differences in the relative contribution of HEIs and their knowledge across UK regions (UNITE Network, 2006; Huggins and Johnston, 2009). There are considerable differences in capabilities across regions and firms to 'effectively absorb knowledge' from universities (Huggins et al., 2008). Furthermore, the recent Sainsbury Review identified the complexity and fragmentation of the mechanisms for knowledge transfer and exchange as a barrier to business engagement. 
There has been a growing evidence base, both in the academic literature and policy documents, indicating that economic development and the welfare of regions can be enhanced through universities' various engagement with the local economy, including research, infrastructure development, education, effective industry-university partnerships, technological innovation and community development (Kelly et al., 2002; Universities UK/HEFCE, 2001; Benneworth and Charles, 2005; Lawton Smith and Bagchi-Sen, 2006; Huggins et al., 2008; SURF et al., 2006; Kitson et al., 2009). An emerging policy concern seems to be the need to align or match regional knowledge producing networks with regional firms' (Uyarra, 2010). However, recent work has also begun to question the high level of policy expectations, with little understanding of the actual processes of knowledge flows, and the extent to which regional economic development can be actually achieved through the utilization of university knowledge (Power and Malmberg, 2008; Huggins, 2008).

Moreover, there is a lack of clear understanding of the influence of devolution processes on regional knowledge flows from universities. These processes are conditioned by a number of factors including the size of the region; the nature of the regional scientific infrastructure; the types of firms and structure of the industrial base; the scientific/technological fields of importance in regions (Crespy et al., 2007), and the institutional multi-scalar dimensions of governance processes. Devolution, defined as 'the relative transfer of power and responsibility from the nation state downward to other units of government and governance' (Jones et al., 2005, p.398), adds further to the dynamics of institutions in the regional science and research landscape, and opens up a number of issues concerning power-relations, different forms of economic governance and public policy. As pointed out by Jones et al (2005) and other contributors in the special issue on devolution and economic governance in Regional Studies, the structures and strategies of devolved economic governance are interrelated in a complex way (Jones et al., 2005), shaped by patterns of intergovernmental interaction and existing governance structures between national and sub-national actors. For instance, when comparing economic development financing and devolved state action across the UK, Cooke and Clifton (2005) identify emerging and different 'institutional structures of economic governance'. 
A burgeoning literature has emerged on sub-national governance in an attempt to interpret these developments (e.g. Keating, 1997; 2005: Pike and Tomaney, 2004, 2009; Jones et al., 2005; Lobao et al., 2009). One of the central questions for regional policy in the devolved policy context in the UK is "whether there is sufficient fiscal decentralisation and capabilities within the regions for regional governance structures to promote growth and convergence' (Frenz and Oughton, 2005). Devolution in Scotland and Wales has introduced a partially autonomous system of higher education, science and research, whilst the situation for the English regions - without an elected regional government structure - remains 'fluid and variable' (Perry, 2007). In England, with the establishment of Regional Development Agencies (RDAs), 'central government-sponsored regionalism' and 'politicization of economic governance' (Jones et al., 2005) co-exist with processes concerning the 'territorialization' of higher education, specifically at the regional level (Warren, et al., 2010).

\section{Methodology and Evidence Base}

The methodology underlying the remainder of this paper takes a mixed methods approach, combining qualitative and quantitative data collection and analysis. The qualitative component relates to a content review of policy documentation emanating from the devolved administrations in Scotland and Wales, as well as the agencies of these administrations. In the main, this documentation relates to the public policy strategies concerning economic development, higher education, science and technology, innovation, and the knowledge economy. In line with the framework indicated by Figure 1, the documents were reviewed to ascertain the underlying policies and strategies relating to university knowledge transfer and universityindustry interaction, or the extent to which university knowledge transfer and university-industry interaction activities form a component of associated regional strategies. This process provided a systematic means of building an evidence base concerning the appropriate policies being formulated in each region following the initiation of political devolution.

The quantitative component relates to the collection and analysis of university-level information concerning general financial data, as well as more specific data on the income received by universities for knowledge transfer and commercialisation 
activities. At the outset we seek to analyse the value added generation by each university in the UK, with a view to aggregating this data at a regional level, in order to ascertain any regional differences, which are presented in Table 1. As a means of achieving this we utilise a consolidation of the annual financial accounts of all universities in the UK made available by the Higher Education Statistics Agency (HESA) relating to overall income, expenditure, and employment data, which allows us to calculate the value added generated by each university, and therefore the contribution of the university sector in each region to total regional Gross Value Added generation. In a corporate context, value added is the wealth created by a firm, which can be measured in a number of ways, but generally reflects sales less costs of bought-in goods and services. Specifically, firm-level value added can be calculated from a company's accounts by adding together operating profit, employee costs, depreciation, and amortisation and impairment charges. Applying a similar methodology, we calculate university value added by adding together surplus, employee costs, and depreciation. This allows us to gauge regional differences in university wealth-generating capacity.

The methodology for analysing the knowledge transfer and commercialisation (KTC) income received by universities consists of an evaluation of secondary data sourced from the annual Higher Education and Business Community Interaction Survey (HEBCIS) which is made freely available by the Higher Education Funding Council for England (although the dataset also covers institutions in Northern Ireland, Scotland, Wales, and Northern Ireland). The HEBCIS dataset covers all universities in the UK and consists of a number of indicators relating to knowledge transfer and commercialisation indicators. In this paper we draw of these metrics to assess how universities in Scotland and Wales are performing regarding their knowledge transfer and commercialisation activity. This is largely based on the income universities receive as a result of undertaking these activities including that received from collaborative research involving both public funding and funding from business, contract research, consultancy contracts, facilities and equipment related services, courses for business and the community, and IP income from patent and licensing activities. In the analysis presented in this paper (Tables 2-4) knowledge transfer and commercialization (KTC) income is defined as including (figures in the parenthesis are the percentage of income by type covering total KTC income across the UK 
higher education sector):collaborative research (28.3\%), contract research (33.2\%), consultancy contracts (12.2\%), facilities and equipment related services (3.9\%), courses for business and the community (20.6\%), and IP income (1.7\%). This methodology provides us with as robust as possible an evidence base concerning the relative engagement of universities in KTC activity, at least based on the income received for such activity.

\section{Governance and Regional Devolution in Scotland and Wales}

The Scottish Government was established in 1999 as the Scottish Executive, from the extant Scottish Office. Following the 2007 Scottish Parliament election, the Scottish Executive was renamed as the Scottish Government by the new Scottish National Party administration. Scotland has a long-established regional development agency (Scottish Enterprise) established in 1991, combined with a 'world-class research base' (Lyall, 2007). In 2005, Higher Education expenditure on R\&D (HERD) was $£ 688$ million. Scotland's HERD as a percentage of GDP ranked top out of all the UK regions. However, there has been a significant gap in business R\&D expenditure between Scotland and the UK and the OECD averages (Scottish Government 2008a). Scotland is also characterized by 'low levels of connectivity between knowledge generating and applying organizations' (Roper et al, 2006).

Scotland was the first region in the UK to seize the opportunity to develop a regional science policy. The regional science policy model in Scotland is promoting new institutionalized strategies of universities and the funding council, including knowledge exchange activities and strategic approaches to research funding and resources in order to compete in a globalizing knowledge economy, with an increased emphasis upon their regional policy agendas through the devolution processes. In $A$ Smart Successful Scotland (Scottish Executive, 2001a), three key themes are identified: (1) Growing Businesses; (2) Ensuring Global Connections and (3) Enhancing learning and skills of Scots. A "Global Connections Strategy" (Scottish Executive, 2001b) sets out Scotland's strategic direction for taking advantage of the opportunities in the knowledge economy and ensuring that Scotland is a globally integrated economy. 
In Wales, the National Assembly for Wales became operational in 1999. The National Assembly has responsibility for developing economic policies within the context of central UK policy frameworks, giving policy makers in Wales more autonomy than before. Of the twelve regions in the UK, Wales is the least competitive with the exception of only North East England (Huggins and Izushi, 2008). It has the lowest level of Gross Value Added per Capita of all UK regions, coupled with levels of pay, productivity, employment and economic activity that are all significantly below the UK average. A lack of regional innovation is identified as a major barrier restricting the growth of the regional economy, which is manifested by relatively low levels of investment in R\&D.

The Welsh Assembly Government's Action Plan for Innovation (WAG, 2002) was one of the first post-devolution policy documents to outline an innovation strategy, with particular emphasis give to the development of incubator facilities through the 'Technium' initiative. Ten Techniums were established throughout Wales housing the full range of incubator support services, and through a combination of specific and non-sector specific incubators they have been designed to allow a balance between clustering and broader networking. The management of seven of the Techniums involves Swansea University, and links with regional academia are considered key to their potential success. Techniums are a key strand of the region's economic development and innovation strategies. This has ensured support from the highest levels of government and academia. The long-term goal for the Techniums is for them to be the foci across Wales for innovation in the knowledge-based industries. However, in some ways, government intervention in the area of university knowledge transfer Wales did not radically alter until 2008-09 (this is discussed in more detail below).

\section{Regional Innovation and Science Policy}

In the field of science, technology and innovation policy, the Scottish Parliament inherited 'both a suite of existing UK policies and also a distinctive Scottish trajectory in regional innovation policy and economic development', characterized as 'concurrent power' (Lyall, 2005). In January 2001, the Minister of Science published A Science Strategy for Scotland (Scottish Executive, 2001c). The Science Strategy stresses the need to maintain a strong science base and increase the effective 
exploitation of scientific research. This resulted in increased resources for university science as well as increased funding for knowledge exploitation initiatives such as the Proof of Concept awards and Royal Society of Edinburgh (RSE) Enterprise Fellowships (Lyall, 2005).

A key recent policy development in Scotland is that of 'research pooling'. This is a regional response to create 'international research excellence' by 'pooling' specific areas of research excellences that are seen to be of strategic importance to Scotland across universities in the region. The development of 'research pooling' initiatives is interesting against the background of devolution as well as the globalization of science, technology and innovation policy on the one hand, and changing higher education policies and environment in the UK on the other (Kitagawa, 2009). Research pooling initiatives may be seen as strategic instruments to enhance research capacity and competitiveness of both universities and the region (and sub-regions), attracting students and professors from abroad, and fostering links to global knowledge flows. ScotCHEM, one of the research pooling initiatives funded by SFC and the universities in Scotland, has developed an industry-led collaboration between the universities involved in the research pooling and the chemical industry sector. In the first year, this will fund 31 industry $\mathrm{PhD}$ studentships in chemistry to be hosted in small and medium sized enterprises (SMEs) within Scotland's chemical industry sector. ${ }^{1}$

Even prior to pre-devolution, there has been a strong policy focus from the Scottish Government, for agencies to 'work in partnership with the universities and research institutes to identify and to help take forward promising new commercialization opportunities as they emerge from the research base' (Reeves et al 2009). These agendas were further developed by the new administration in 2007 as part of the Government Economic Growth Strategy (GES), which sets the target to raise Scotland's GDP growth rate to the UK level by 2011 and to match GDP growth rate of the small independent EU countries by 2017. The recent publication by the Scottish Government of 'Science for Scotland' (2008b) further endorsed the promotion of commercialization from research bases. The Scottish Government sees the contribution of higher education sector in Scotland as 'a sector in its own right' and higher education has been identified as one of the seven key sectors of the Scottish 
economy. There has been a growing commitment to knowledge exchange from academic sector, promoted by the funding council. The Scottish Government has acknowledged that knowledge exchange can and should be used to improve Scotland's social and economic well-being (SFC, 2007).

In Wales, alongside the Technium programme policy intervention has further supported and encouraged commercialization developments through the Wales SpinOut Programme, which concentrates on the development of arrangements designed to create high quality businesses from the higher education sector. Complementary to the Spin-Out Programme, the 'Know How Wales' initiative, launched in 1999, provides a gateway to university facilities and expertise for existing companies seeking assistance to expand or establish new products and markets. The Lambert Review (Lambert, 2003) identifies the role of Know How Wales as good practice in linking business and academia. In 2001, the Knowledge Exploitation Fund (KEF) was launched to work within the Welsh university community (and further education institutions) to 'generate a more entrepreneurial and innovative culture; produce more skilled trainers; increase the training interaction with Welsh industry and accelerate the commercial exploitation of research'. KEF had an annual budget of $£ 16$ million including European Structural Funds support (WAG, 2004).

In general, university knowledge transfer in Wales has formed a key strand of innovation and science policy, and probably more so than in Scotland. A key reason underlying the focus on universities as agents of knowledge transfer is that Wales only has two public sector research establishments: the Institute of Grassland and Environmental Research (IGER) at Aberystwyth, and the Centre for Ecology and Hydrology (CEH) at University of Wales, Bangor. The Science Policy strategy for Wales was not published until (WAG, 2006), with it stating that: "no one now builds new government research establishments... It may be a regrettable situation but it is a situation which has to be faced.' (p. 4). However, the coalition Welsh Assembly Government of Labour and Plaid Cymru established in 2007 resulted in a reversal of this view, with the WAG stating 'we will work to establish a National Science Academy....we will establish new National Research Centres. (WAG, 2007, p. 25). However, despite the pronouncements apparent development of such an academy and research centres have been to slow to emerge. 
Indeed, the indications are that rather than new funding being made available, finance will consist of that already allocated by WAG. For instance, more than $£ 3$ million is due to provided to a number of Welsh universities to establish a Wales Institute of Visual Computing (WIVC) with the aim of developing an internationally-leading research capacity. Although this is applauded, it would be appear that connecting universities strengths is something which should be additional to, rather than instead of, proposed new knowledge and research infrastructure funded thorough already allocated finance. This has led some to claim that 'by seeking to develop a Knowledge Economy 'on the cheap', the Assembly Government risks losing out to competitor economies across Europe and within the UK' (HEW, 2008).

\section{The University Sector}

In Scotland, there are 20 universities and higher education institutions, which are funded by SFC. Scottish universities are generating significant income from knowledge transfer activities. In the two year period between 2005 and 2007, the total reported income from knowledge exchange activities amounted to $£ 583$ million, consisting of external research grants, contracts and consultancy (64\%), licensing $(4 \%)$, venturing (8\%), enterprise (2\%), CPD (18\%) and outreach (4\%) (Scottish Government, 2008c). The Scottish Funding Council (SFC) was established in 2005 by combining the roles of the former Scottish Further Education Funding Council (SFEFC) and the Scottish Higher Education Funding Council (SHEFC). SFC invests more than $£ 1.7$ billion in 2009-10 in universities and colleges in Scotland. For universities, allocations are split into two main elements: a Horizon Fund for investments in 'projects that are intended to bring economic, social, cultural and other benefits to Scotland, which includes funding in support of knowledge exchange; and a General Fund, which provides universities with a flexible funding stream to support their core activities of teaching, research and knowledge transfer' (SFC, 2009). SFC adopts a broad view to knowledge transfer, more frequently referred to as 'knowledge exchange', which includes public engagement, cultural engagement and public policy as well as commercialisation and technology transfer. Funding for knowledge transfer ( 25 million per annum) has been income metric-led with a growing strategic element. SFC's new Horizon Fund ${ }^{2}$ will mean that the strong majority of funds will be projectbased including a new SFC Innovation Voucher Scheme. 
The higher education sector in Wales consists of 11 institutions (previously 12, until the merger in 2007 of the Royal Welsh College of Music and Drama). The annual economic contribution that Welsh universities make to the regional economy is estimated to be more $£ 2$ billion, when direct and indirect effects are taken into consideration, supporting over 23,000 jobs (HEW, 2009). The university sector is by far the major producer of $R \& D$ in Wales, with Cardiff University spending the majority of the total university $\mathrm{R} \& \mathrm{D}$ expenditure. In general, there has been little history of interaction between the higher education sector and businesses in the region, with universities often targeting large-scale industrial research projects rather than providing services for SMEs in their localities, which is often considered by universities to be non-cost-effective in comparison to working with large firms.

In general, higher education policy in Scotland is largely devolved, while in Wales powers over higher education are devolved to the Welsh executive body, the Welsh Assembly Government, but not until now to the National Assembly for Wales, although this could happen in the future (Universities UK, 2008). In general, a key concern for the devolved administrations is that despite increased autonomy, the nature of geographic variations across the UK in the demand for higher education mean that English universities are becoming markedly better funded in comparison to institutions in Scotland and Wales. This is especially pronounced in Wales, which still does not have full legislative power for the higher education sector, where the investment gap with England has been estimated to be of the order of $£ 60$ million annually (Universities UK, 2008).

More specifically, the funding bodies in the devolved administrations (e.g. SFC in Scotland and HEFCW in Wales) have recognized the impact of the concentration of research funding in a few institutions in England on their institutions' competitive ability to bid for those research funds available on a UK-wide basis (Universities UK, 2008, p.47). The UK Government's policy to shift research funding to a fewer number of departments is likely to lead to a major redistribution of research activities and to bring about highly differential effects (Universities UK, 2003). In England, as a result of its funding mechanisms, there has been a growing concentration of research funding in a few institutions such as Cambridge and Oxford Universities, and Imperial 
College, further intensifying resources in the so-called "golden triangle". Consequently, there is growing 'variability' in the capability of universities to conduct research and to transfer knowledge in their regions and beyond (Huggins, 2008). This conditions not only on institutional research profiles but also regional research capacity and diversity.

Table 1 highlights the value added per employee by universities in the UK aggregated at a regional level. Significantly, average value added per employee for universities in both Scotland and Wales is less than the overall UK average. The final column of Table 1 indicates the relative contribution of GVA generated by the higher education sector to regional GVA as a whole. Across the UK's regions, the higher education sector in Wales is the biggest contributor to regional GVA, providing $1.36 \%$ of total regional GVA. The contribution of the higher education sector in Scotland to regional GVA is also above the UK average, but it is considerably less than that in Wales. These differences have a clear bearing on policies promoting the role of universities as catalysts of economic development. In particular, it suggests that while the more competitive regions may be able to benefit from being the home of the majority of the UK's most prestigious and wealthiest universities, more lagging regions - such as Wales and to a lesser extent Scotland - are likely to contain a greater concentration of institutions that are less able to compete in the higher education marketplace with their more prestigious counterparts.

Table 1 About Here

\section{University Knowledge Transfer Policies}

Since its inception in 2001/2, Knowledge Transfer Grant (KTG) is the main funding stream for knowledge transfer/exchange in Scottish HEIs. In 2008-09, the KTG totaled $£ 21.5$ million for universities and $£ 3$ million for colleges. The grant supports the infrastructure universities and colleges need to maximise active knowledge exchange with third parties. Funding is largely allocated on the basis of the relative volume of income from knowledge exchange activity as measured by SFC's metrics (HEFCE, 2008). Cullen (2009) argues that KTG has contributed to 'a much greater awareness of KT, a much broader understanding of the range and objectives of KT and, importantly, an embedding of KT within the institutional strategy'. The SFC 
created a new strategic knowledge exchange grant in 2008-09 - the Strategic Priority Investment in Research and Innovation Translation (SPIRIT), and this will be set at $£ 3.8$ million in 2009-10 and will enable strategic knowledge exchange projects to be targeted. SPIRIT meets SFC's corporate plan objectives to 'improve the flow of knowledge, expertise and ideas, to businesses, enterprises and public services' and to 'work with key partners to develop knowledge exchange activities that enhance innovation in public policy and practice in Scotland and strengthen the policy community' (SFC, 2006). SPIRIT will facilitate a range of strategic knowledge exchange investments including projects of national priority as well as those prioritized by SFC.

In addition to KTG and SPIRIT, SFC also has a small grant which targets the promotion of knowledge transfer (PKT). The PKT grant (£470k in 2007-08) is used to promote good practice in, raise awareness of, and improve information about, research expertise, commercialization and knowledge exchange more generally. The grant funds initiatives such as Interface, Technology Ventures Scotland and Connect, as well as research and evaluations that provide an evidence base for policy development. Funded projects are often joint activities with other stakeholders recognizing that they sit at the boundary between the supply of, and demand for, knowledge and innovation support. For example, Interface - the knowledge connection for business - was set-up in 2005 and is funded by SFC. It is a central point of access for industry to Scotland's research base that provides a service designed to address the growing demand from businesses seeking to engage with academia for knowledge and expertise. SFC also funds the Scottish Institute of Enterprise (SIE), which aims to promote an entrepreneurial culture in higher education by providing opportunities for students and researchers to obtain business and management skills, and so enhance the contribution of higher education to growth in the economy.

Scottish Enterprise has taken several proactive approaches to strengthening the commercialization of the Scottish academic research base through initiatives such as the Intermediary Technology Institutes, the Enterprise Fellowship Programme and the Proof of Concept awards. These programmes were set up to address the gap between where Scotland has considerable strength in its science base but less success in 
commercialization (Roper et al., 2006; Lyall, 2007). In 1999, the Proof of Concept Fund was established and provided $£ 33$ million of funding in 2004 available over a six year period. When the Proof of Concept Programme was first established there were no comparable initiatives within the UK or mainland Europe. Due to the relatively weak business demand for state of the art research, it was considered to be critical that new companies were created 'to ensure the most promising ideas emerging from the research base are taken forward'. The Proof of Concept Programme responds to this opportunity by providing funding support for technical activity, protection of IP, market assessment and business model development (Reeves et al., 2009). An independent evaluation undertaken in 2006 found that the Programme generated $£ 125$ million gross value added (GVA) for the Scottish economy. ${ }^{3}$

The key post-devolution knowledge transfer and commercialization activities funded in Wales included: Centres of Excellence for Technology and Industrial Collaboration; the Wales Spinout Programme; a Patent and Proof of Concept Fund; Collaborative Industrial Research Partnerships; Technology Transfer Networks, and Technology Transfer Centres. University knowledge transfer policy in Wales is supported via the Higher Education Funding Council for Wales (HEFCW)'s Third Mission Fund, with the bulk of the funding allocated on a formula basis. From 2008, a substantial increase in the support available for third mission activities has been available via the Welsh Assembly, which was successful in attracting around $£ 50$ million from the European Regional Development Fund (ERDF) for two knowledge exploitation and transfer programmes jointly branded as Academia for Business (A4B) (HEFCE, 2008).

This is a major policy overhaul with existing funded activities repackaged under the two programmes: Knowledge Exploitation Capacity Development; and Knowledge Transfer and Industrial Research. Overall, A4B is supported by a six-year $£ 70$ million funding package from the Welsh Assembly Government and the ERDF. A4B is advertised as consisting of 'the best elements' of previously funded programmes, particularly the Knowledge Exploitation Fund and the Centres of Excellence. A4B aims to support a range of activities in higher and further educational institutions to develop more effective knowledge transfer mechanisms, to commercialize their 
Intellectual Property, develop new products and processes, increase business investment in R\&D and develop and exploit the research base. Key targets for A4B are: to stimulate new business ideas and help launch as least sixty new products and processes onto the market; act as a catalyst to leverage in an additional $£ 9 \mathrm{~m}$ of funding into research projects and support more than $120 \mathrm{R} \& \mathrm{D}$ collaborations; and perhaps most ambitiously to help at least 2,000 businesses to benefit from collaborating and working with universities.

A leading example of knowledge transfer activity in Wales is Cardiff University's 10year $£ 25$ million agreement with Biofusion, a specialist commercialization company listed on the London Stock Exchange's Alternative Investment Market (AIM), to provide a ring-fenced fund to invest in companies spun out from the university's research base. The Wales Gene Park initiative also successfully bid to become one of six prestigious gene parks in the UK. Funded by the Welsh Assembly Government, the UK Government and the NHS, the Park aims to exploit the bioscience expertise of five Welsh universities. The first phase of this development, a virtual gene park, is underway but funding issues appear to have somewhat dogged overall development in light of those expected by the initiative's key players.

The requirement to internationalize the knowledge networks of Wales' universities has most been prominently recognized by the University of Wales federated institutions through the introduction of The Prince of Wales Innovation Scholarship Programme, which aims to 'attract the world's most talented graduates to work with Welsh businesses'. The programme is seeking to recruit 1,000 of the world's best graduates between 2009 and 2012 to help improve research and development capability and cutting edge thinking in Wales. Also, an independent review of the need to improve of the commercialization of the knowledge residing in Welsh universities recommended the creation of advisory panels comprising experienced and successful entrepreneurs, which are currently being piloted in three institutions (Gibson, 2007).

At the time of writing it is impossible to say whether or not the new policy approach in Wales will be more successful than its predecessors, but the capturing of significant European finance for these activities does provide a very real opportunity to develop a 
system of sustained and coherent support, which was a major criticism, recognized by WAG, of previous modes of intervention. Any real semblance of the development of a regional innovation system has been problematic to establish given the apparent dominance of Cardiff University, and more latterly Swansea University, in the area of higher education knowledge commercialization, coupled with a lack business sector actors. Although Wales has had extensive autonomy in recent years to establish policies tailored to creating interventions best suited to catalyzing knowledge-driven regional development, there is as yet little evidence of the accruing of economic returns from these interventions, highlighting the necessity for patience and long-term thinking within this area of policy intervention.

\section{Complementary Innovation Infrastructure}

Alongside, university knowledge transfer initiatives, it is important to highlight the complementary innovation infrastructure that regional policymaking has facilitated. In Scotland a key development was the establishment of the Intermediary Technology Institutes (ITIs), which were created with the aim of building on the strengths of the Scottish economy by improving the commercialization of research. Scottish Enterprise committed $£ 450$ million investment to the ITIs. ITIs fulfill a coordinating task that helps to identify, commission, and/or acquire and diffuse pre-competitive research. The creation of ITI Scotland in 2003 was a specific intervention by the Scottish Executive to help to address the 'Growing Businesses' theme identified in $A$ Smart Successful Scotland, focusing on strengthening the link between Scotland's research base and business innovation and addressing low levels of business $\mathrm{R} \& \mathrm{D}(\mathrm{OECD}, 2004)$. A particular emphasis of the ITI is on Scottish universities, research institutes, as well as existing and nascent SMEs in the fields of communication technology and digital media, life sciences and energy sectors. Up to 2009, ITI Scotland committed over $£ 150$ million in research programmes (Edgar, 2009) while in 2009, it was announced that Scottish Enterprise would integrate ITIs within the agency's wider research, commercialisation and innovation operations. There are also several innovation schemes to help Scottish universities work with SMEs in response to the problem of weak links between universities and small industry in Scotland. The SFC's new Innovation Voucher Scheme aims to promote interactions between HEIs and SMEs. The Scottish Government's SEEKIT programme is designed to support projects that will promote co-operation in R\&D and 
knowledge transfer between SMEs and the Scottish public sector science base (e.g. universities, Research Institutes, Technology Transfer Organizations, NHS Trusts etc).

As highlighted above, a key policy development in Wales is the Technium programme. Links with academia are regarded by policymakers as critical to the success of the Techniums, and they provide space for university spin-outs and house possible graduate employers. As Abbey et al. (2008) note, partnership arrangements with Fudan University in Shanghai has actually resulted in two high-technology Chinese firms entering one of the Techniums. Although the early-stage success of the Technium initiative has been disputed (Cooke and Clifton, 2005; Abbey et al., 2008), they at least herald a long-term investment in the knowledge-based infrastructure that is lacking in Wales. Overall, some estimates suggest that the Technium programme has created more than 550 jobs, worth some $£ 74 \mathrm{~m}$, with additional estimated benefits of 760 jobs indirectly supported, worth a further $£ 63 m$ (HEW, 2009). However, most of the success has been associated with a small number of Techniums, especially those with close relationships with academia. Techniums with less close links have struggled to find appropriate tenants, and by 2010 WAG was considering a rationalization in their number.

\section{University Knowledge Transfer 'Performance'}

Table 2 indicates total knowledge transfer and commercialization (KTC) income per HEI employee at a regional level across the UK. The list is headed by Wales, with Scotland also having a level of KTC income per employee above the UK average. Further scrutiny of the data finds that KTC income in Wales has been significantly boosted in recent years due to a rapid rise in collaborative research income received by one institution - Swansea University in connection with the development of the Technium initiative. Despite this boost, HEIs in Wales have only increased their KTC income between 2001/02 and 2006/07 slightly more than the UK average (120.4\% cf. $118.5 \%)$. However, this is a higher rate than that achieved in Scotland over the same period. The English regions of the North West, South, West Midlands, Yorkshire and Humber have shown the biggest increases over the period, although there is significant variability across England as a whole. Perhaps the most marked feature of the data is that for the UK as a whole recorded, KTC income has more than doubled 
over a five year period (which may be a result of better accounting on behalf of universities as much as actually increases to income streams).

The right-hand column of Table 2 lists the proportion of commercialization income HEIs source from within their region (with the exclusion of collaborative research income for which source data is unavailable). It is highly noticeable that HEIs in Wales source only $8 \%$ of their commercialization income from within the region, far lower than HEIs in any other region (with Scotland on a relative par with most English regions). This potentially indicates the existence of a lack of demand from firms within the region for the types of knowledge Welsh universities are capable of supplying. This confirms the extent to which regional contexts are an important influencing factor on the economic and innovative performance of universities.

Table 2 About Here

In Scotland, three institutions - the universities of Edinburgh, Glasgow, and Strathclyde - account for more than one half of the KTC income received by the higher education sector (Table 3). A further three institutions - Aberdeen, Heriot-Watt, and Dundee - account for a further one third. This indicates a relatively high spread of income and activity across the region's universities, which is in stark comparison to that in Wales where two institutions - Cardiff and Swansea - receive more than two thirds of total income (Table 4). Although this represents a significant concentration of income and activity it is a shift from the previous situation whereby activity was largely dominated by Cardiff University alone. The growth in knowledge transfer activity in Swansea, particularly that associated with the Technium initiative, indicates the development of a more balanced picture of higher education involvement in knowledge transfer in Wales. However, the gap between the universities of Cardiff and Swansea and other HEIs in the region highlight that more needs to be done if Wales is to achieve the level of distributed activity found in Scotland.

Tables 3 and 4 About Here

\section{Discussion and Policy Implications}


There are a number of policies that governments pursue when seeking to promote innovation, including policy initiatives to foster the commercialization of university research, encouraging firms to invest in $R \& D$, or encouraging the activities of venture capital funds. As Driver and Oughton (2008) argue, the important task for public policy is to characterize accurately the interplay of causal factors in innovation expenditure', although 'identifying the nature of what is required (or how to intervene) is methodologically difficult'. The review of policy interventions in the two case study regions identify several similarities, as well as differences, in terms of regional intervention towards strengthening the role of the university sector in constructing regional innovation systems through strengthening knowledge transfer from higher education sector.

As we have discussed, knowledge transfer is seen as one of the priority policy agendas in the UK science and innovation policies. Since their establishment in 1999, the devolved governments in Scotland and Wales have facilitated partnership development between universities and industry to support more effective collaboration between the knowledge and research base and the business community, particularly within identified key regional growth sectors. In both Scotland and Wales, knowledge transfer from higher education sector is promoted as part of regional innovation system development, and each process has been shaped by different policy and politics. Both Scotland and Wales have developed substantial knowledge transfer funding programmes over the decade.

Scotland and Wales share a number of similar industrial structures, constraints in economic development, and to a large extent have developed similar science-based innovation strategies in which universities play central role in terms of commercialization and knowledge transfer. One of the key differences identified in the approaches adopted in the knowledge transfer strategies is based on the economic and institutional conditions in each region. Leading regions for innovation are often those with multiple nodes of research strength including universities, government laboratories, non-profit research organizations, and private-sector R\&D units (Youtie and Shapira, 2008). Regions in economic 'catch-up' positions, without multiple nodes of knowledge generation, tend to hope that their universities will serve as an 'anchor tenant' (Agrawal and Cockburn, 2003) to attract other private-sector R\&D facilities. 
Scotland certainly has some research strengths within its universities, primarily in Edinburgh, Glasgow, and the development of research pooling initiatives in Scotland is an exemplar in building critical mass of global 'research excellence', with a number mechanisms in place to further strengthen 'industrial relevance' at the regional level (Kitagawa, 2010). In Wales, there is only a single dominant university and a lack of other kinds of research and industrial partners with advanced capabilities with whom the university can interact, although there has been significant policy intervention exemplified by the Technium initiative. Nevertheless, public and private R\&D investment levels in Wales remain below par, and the region has lowest proportion of firms engaged in knowledge-based activities across all UK regions.

There are a number of examples of institutionalized strategies for innovation and knowledge transfer in Scotland, connecting knowledge bases and industry, which are promoted, fostered and supported through the process of devolution. However, there are criticisms that Scotland's 'post-devolution' science policy seems to continue to focus on the 'supply side', namely the science base in Scottish universities, disregarding the 'demand side' role that could be played by firms (Lyall, 2007, Roper et al., 2006). As already mentioned, there are several existing demand side policies, and increasing focus on demand side policies in Scotland, and probably more so in Wales, are required alongside the supply-side intervention that has formed the focus of this paper. This hints at the next phases of intervention devolved regional governments will be required to tackle. Whilst regional policy has clearly incentivized universities to seek engage with the business community, incentivizing the business community is likely to form a much tougher challenge.

The additional autonomy Scotland has enjoyed, compared with Wales, means that it represents a more advanced and evolving innovation policy model, which is fairly well advanced with regard to its organizational models, which includes infrastructure such as the ITIs. Wales, as well as regions elsewhere, can learn from the Scottish experience of institutionalized strategies for innovation and knowledge transfer as well as the collaborative environment fostered by their higher education sector.

Universities, it is clear, have an important role to play at regional level in the development of the knowledge economy within the devolved policy structures. 
However, for universities, strategic balance is also important. There is a need to assess the benefits to universities relating the outcomes of knowledge transfer activities to the core mission of teaching and research in their own institutional settings and strategies (Warren et al. 2010). Nevertheless, establishing regional cooperation across universities is considered to be an important element of creating critical mass in less competitive and more peripheral areas (Siegel et al., 2007).

Increasing evidence suggests that the best use of knowledge is made by linking it globally (or least non-regionally/locally) (Huggins and Johnston, 2009). Both Scotland and Wales are encouraging international flows of knowledge by attracting talent from overseas (e.g. Research pooling initiative; The Prince of Wales Innovation Scholarship Programme). In order to embed knowledge transfer from universities as part of wider innovation process in the wider context of economic governance in the globalizing knowledge economies, science and innovation policy should include wider elements of 'proximity' than a geographical one (Boschma, 2005; Wink, 2008).

The complexity of the devolution process derives from the interest-conflicts of the various actors involved, and the differences in legitimacy that they share. Most importantly, the interests of sub-national and national governments tend to be at odds across the component factors of devolution. The balance between these two extremes will depend upon the relative strength, or, in political terms, legitimacy, of the two tiers of government. (Rodríguez-Pose and Gill, 2003). For instance, despite the value that devolution and regional autonomy brings to developing these agendas, there is a certain amount of nervousness among some stakeholders in Wales that the strategic coherence of UK innovation policy promoted by the UK Government may result in a focus that is rather England-oriented, and does not take adequate account of the devolved regions. Although the ability to establish regional policies to catalyze the development of innovation systems requires far more than appropriate resource allocation (Koschatzky and Kroll, 2007), a continued lack of funding does appear to be an on-going constraining factor limiting the engagement of universities in knowledge-based economic development.

There are a number of remaining issues to be investigated in the future. The analysis in this paper has revealed challenges in terms of evaluating the impact of knowledge 
transfer and commercialization from research bases in their regions, especially in measuring wider non-quantifiable impacts of policy intervention. The real impact of initiatives such as the construction of business incubators, the delivery of venture and seed funds and regional innovation support services on regional competitiveness may not be achieved for many years after funding ceases (Warren et al. 2010). There is also a need for policymakers at both regional and national levels to recognize the complexity of interactions between the local, national and global levels, the institutional multi-level dimensions, and the co-evolution of science and innovation policy, especially through devolution processes. This has to be combined with spatial resource management and institutional strategies on the one hand, and issues concerning joined-up public policies from multi-level perspectives on the other.

\section{Acknowledgements}

We are grateful to the Economic and Social Research Council (Grant Award Reference: RES-171-25-0023 and RES-594-28-0001) for funding the research upon which this paper is based. We are also grateful to three reviewers for their comments on an earlier version of the paper. The usual disclaimers apply.

\section{References}

Abbey J., Davies G. and Mainwaring L. (2008) Vorsprung durch Technium: Towards a system of Innovation in South-west Wales, Regional Studies 42, 281-293.

Agrawal A. and Cockburn I. (2003) The anchor tenant hypothesis: Exploring the role of large, local, R\&D-intensive firms in regional innovation systems, International Journal of Industrial Organization 21, 1227-1253.

Benneworth P. and Charles D. (2005) University spin off companies and the territorial knowledge pool: Building regional innovation competencies? European Planning Studies 13, 537-557.

Boschma R (2005) Proximity and innovation: A critical assessment, Regional Studies 39, 61-74.

Boucher G., Conway C. and Van Der Meer E. (2003) Tiers of engagement by universities in their region's development, Regional Studies 37, 887-897.

Charles D. (2003) Universities and territorial development: Reshaping the regional role of UK universities, Local Economy 18, 7-20.

Chatterton P. and Goddard J. (2000) The response of higher education institutions to regional need, European Journal of Education 35, 475-496.

Cooke P. and Clifton N. (2005) Visionary, precautionary and constrained 'varieties of devolution' in the economic governance of the devolved UK territories, Regional Studies 39, 437-451.

Crespy C., Heraud J.A. and Perry, B. (2007) Multi-level governance, regions and science in France: between competition and equality, Regional Studies 41, 10691084.

Cullen K. (2009) The development and implementation of knowledge transfer metrics in Scotland, Paper presented at the 7th Triple Helix International Conference, Glasgow, 17-19 June. 
Driver C. and Oughton C. (2008) Dynamic models of regional innovation: Explorations with British time-series data, Cambridge Journal of Regions, Economy and Society 1, 205-217.

ESRC (2009) Strategic Plan 2009-2014 http://www.esrcsocietytoday.ac.uk/ESRCInfoCentre/strategicplan/impact/ accessed 12 April 2010.

Edgar J. (2009) Intermediary Technology Institutes: Their role in promoting innovation and economic development in Scotland, Paper presented at the 7th Triple Helix International Conference, Glasgow, 17-19 June.

Etzkowitz H. (2002) MIT and the Rise of Entrepreneurial Science, Routledge, London and New York.

European Commission (2007) Improving knowledge transfer between research institutions and industry across Europe: embracing open innovation. http://ec.europa.eu/invest-inresearch/pdf/download_en/knowledge_transfe_07.pdf accessed 10 July.

Florida R. (1999) The role of the university: Leveraging talent, not technology, Issues in Science and Technology 15, 67-73.

Frenz M. and Oughton C. (2005) Innovation in the UK Regions and Devolved Administrations: A Review of the Literature for the Department of Trade and Industry and the Office of the Deputy Prime Minister http://www.berr.gov.uk/files/file9651.doc accessed 20 February 2009.

Gibson, S 2007 Commercialisation in Wales: A Report by the Independent Task and Finish Group, Independent Review of Publicly Funded Commercialisation Activities in Wales, Cardiff.

Goddard, J. and Chatterton, P. (1999) 'Regional Development Agencies and the Knowledge Economy: Harnessing the potential of universities', Environment and Planning $C$ 17: 685-699.

Goodwin M., Jones M. and Jones R. (2005) Devolution, constitutional change and economic development: Explaining and understanding the new institutional geographies of the British state, Regional Studies 39, 4421-4436.

HEFCE (2008) Higher Education -Business and Community Interaction Survey 200607, Higher Education Funding Council for England, Bristol

HEW (2008) Universities driving the emergence of the knowledge economy in Wales, Higher Education Wales, HEW final evidence to the National Assembly's Enterprise \& Learning Committee -July, Cardiff

HEW (2009) Leading the Economic Recovery in Wales: Universities Building for the Future, Higher Education Wales, Cardiff

Huggins R. (2008) Universities and knowledge-based venturing: Finance, management and networks in London, Entrepreneurship and Regional Development 20, 185-206.

Huggins R. and Izushi H. (2007) Competing for Knowledge: Creating, Connecting, and Growing, Routledge, London.

Huggins R. and Izushi H. (2008) UK Competitiveness Index 2008, Centre for International Competitiveness, University of Wales Institute, Cardiff)

Huggins R. and Johnston A. (2009) The economic and innovation contribution of universities: A regional perspective, Environment and Planning C: Government and Policy 6, 1088-1106.

Huggins R., Johnston A. and Steffenson R. (2008) Universities, knowledge networks and regional policy, Cambridge Journal of Regions, Economy and Society 1, 321-340. 
Jones M., Goodwin M., and Jones R. (2005) State modernization, devolution and economic governance: An introduction and guide to debate, Regional Studies 39, 397-403.

Keating M. (1997) The invention of regions: Political restructuring and territorial government in Western Europe, Environment and Planning C: Government and Policy 15, 383-398.

Keating M. (2005) Higher Education in Scotland and England after Devolution, Regional and Federal Studies 15, 423-435.

Kelly U., Marsh R, McNicoll I. (2002) The Impact of Higher Education Institutions on the UK Economy, Universities UK, London.

Kitagawa F. (2007) The regionalization of science and innovation governance in Japan? Regional Studies 41, 1099-1114.

Kitagawa F. (2009) Creating critical mass of research excellence in the region: The case of Scottish research pooling initiatives, European Planning Studies 17,487495.

Kitagawa, F (2010) Pooling Resources for Excellence: An Evolution of Universities as Networked Organisations, Minerva. 48, 169-187.

Kitson M., Howells J., Braham R. and Westlake S. (2009) The Connected University: Driving Recovery and Growth in the UK Economy, NESTA, London.

Koschatzky K. and Kroll H. (2007) Which side of the coin? The regional governance of science and innovation, Regional Studies 41, 1115-1128.

Lambert R (2003) Lambert Review of Business-University Collaboration: Final Report, HM Treasury, HMSO, London. Available at http://www.hmtreasury.gov.uk/d/lambert_review_final_450.pdf access 20 February 2009.

Lawton Smith H. (2007) Universities, innovation, and territorial development: A review of the evidence, Environment and Planning C: Government and Policy 25, 98-114.

Lawton Smith H. and Bagchi-Sen S. (2006) University-industry interactions: The case of the UK biotech industry, Industry and Innovation 13, 371-392.

Lobao L., Martin R. and Rodríguez-Pose, A (2009) Editorial: Rescaling the state: New modes of institutional-territorial organization, Cambridge Journal of Regions, Economy and Society 2, 3-12.

Lyall C. (2005) Scotland's science strategy: An exercise in concurrent power? Scottish Affairs 52, 51-70.

Lyall C. (2007) Changing boundaries: The role of policy networks in the multi-level governance of science and innovation in Scotland, Science and Public Policy 34, 3-14.

Jessop B. (2004) Hollowing out the nation-state and multilevel governance, in: Kennett P. (Ed) Handbook of Comparative Social Policy, Edward Elgar, Cheltenham, 11-25.

NCIHE (1997) Higher Education in the Learning Society: Report of the National Committee, HMSO, London.

OECD (2004) Global Knowledge Flows and Economic Development, OECD, Paris.

Pavitt K. (1998) The social shaping of the national science base, Research Policy 27, 793-805.

Perry B. (2007) The Multi-level governance of science policy in England, Regional Studies 41, 1051-1968.

Perry B. and May T. (2007) Governance, science policy in England, Regional Studies 41, 1039-1050. 
Pike A. and Tomaney J. (2004), Sub-national governance and economic and social development, Environment and Planning A 36, 2091-2096.

Pike A. and Tomaney J. (2009) Sub-national governance and economic development: The case of England in post-devolution UK, Cambridge Journal of Regions, Economy, and Society 2, 13-34.

Porter M.E. and Ketels C.H.M. (2003). UK Competitiveness: Moving to the Next Stage, Department of Trade and Industry' London.

Power D. and Malmberg A. (2008) The contribution of universities to innovation and economic development: in what sense a regional problem? Cambridge Journal of Regions, Economy and Society 1, 233-245.

Reeves C., Hansen W., Laird G., Taylor E. and McCarthy, C (2009) Supporting commercialisation in Scotland: Policy, delivery and impacts, Paper presented at the 7th Triple Helix International Conference, Glasgow, 17-19 June.

Rodríguez-Pose A. and Gill N. (2003) The global trend towards devolution and its implications, Environment and Planning C: Government and Policy 21, 333-351.

Rodríguez-Pose A. and Gill N. (2005) On the 'economic dividend' of devolution, Regional Studies 39, 405-420.

Roper S., Love J., Cooke P. and Clifton N. (2006) The Scottish Innovation System: Actors, Roles \& Actions Scottish Executive, available at http://www.scotland.gov.uk/Resource/Doc/89713/0021562.pdf

Sainsbury D. (2007), The Race to the Top: A Review of Government's Science and Innovation Policies, HMSO, London.

Scott, A.J. (Ed) (2001) Global City-Regions: Trends, Theory, Policy, Oxford University Press, London.

Scottish Executive (2001a) A Smart, Successful Scotland. Ambitions for the Enterprise Networks, Scottish Executive, Edinburgh.

Scottish Executive (2001b) Scotland: A Global Connections Strategy, Scottish Executive, http://www.scotland.gov.uk/Resource/Doc/158429/0042932.pdf Accessed 14 June 2009.

Scottish Executive (2001c) A Science Strategy for Scotland, Scottish Executive, Edinburgh http://www.scotland.gov.uk/Resource/Doc/158401/0042918.pdf Accessed 14 June 2009.

Scottish Funding Council (2006) SFC Corporate Plan 2006-2009 Learning and innovation: helping to deliver Scotland's strategy for the future, Accessed 14 July 2009. http://www.sfc.ac.uk/reports_publications/reports_publications.aspx?Search=Sc ottish\%20Funding\%20Council\%e2\%80\%99s\%20Corporate\%20Plan\%20200609.\&Type=Reports\%20and\%20publications\&Sector=-1 Accessed 14 June 2009.

Scottish Funding Council (2007) Knowledge Exchange on Public Policy, Autumn, 2007 Issue 1.

Scottish Funding Council (2009) Corporate Plan 2009-2012 Outcome 3 Knowledge Exchange http://www.sfc.ac.uk/web/FILES/AboutTheCouncilInformationLeaflets/SFC_O utcome3_Knowledge_final.pdf Accessed 3 December 2010.

Scottish Government (2008a) Innovation and Research \& Development: R\&D Business Expenditure High Level Summary of Statistics Trend http://www.scotland.gov.uk/Topics/Statistics/Browse/Business/TrendRandDBu siness Accessed 14 July 2009. 
Scottish Government (2008b) Science for Scotland http://www.scotland.gov.uk/Resource/Doc/247013/0069782.pdf Accessed 14 June 2009.

Scottish Government (2008c) A Strategic Framework for Science in Scotland -2008: Report of the Knowledge Exchange Working Group http://www.scotland.gov.uk/Publications/2008/11/28105610/5 Accessed 14 June 2009.

Siegel D., Wright M. and Lockett A. (2007) The rise of entrepreneurial activity at universities: organizational and societal implications, Industrial and Corporate Change 16, 489-504.

Sotarauta M. and Kautonen M. (2007) Co-evolution of the Finnish national and local innovation and science arenas: Towards a dynamic understanding of multilevel governance, Regional Studies 41, 1085-1098.

Srinivas S. and Viljamaa K. (2008) Emergence of economic institutions: Analysing the third role of universities in Turku, Finland, Regional Studies 42, 323-341.

SURF, IPP, CURDS, PREST, CRIC (2006) The Embedded University in the 'Science Economy': Capacities, Contexts and Expectations - A Research Agenda, A Report to the ESRC, ESRC, Swindon.

Turok, I. (2008) A new policy for Britain's cities: Choices, challenges, contradictions, Local Economy 23, 149-166.

UNITE Network (2006) 1st Interim Report and Preliminary Gap Analysis, A Report to the ESRC, ESRC, Swindon.

Universities UK/HEFCE (2001) The Regional Mission: The Regional Contribution of Higher Education. National report, Universities UK, London.

Universities UK (2003) Funding Research Diversity: The Impact of Further Concentration on University Research Performance and Regional Research Capacity.

Available

at http://www.universitiesuk.ac.uk/Publications/Bookshop/Documents/funding_su m.pdf Accessed 14 June 2009.

Universities UK (2008) Devolution and Higher Education: Impact and Future Trends, Universities UK, London.

Uyarra, E. (2010) Conceptualizing the Regional Roles of Universities, Implications and Contradictions, European Planning Studies 18, 1227 - 1246

WAG (2002) Wales for Innovation: The Welsh Assembly Government's Action Plan for Innovation, Welsh Assembly Government Cardiff.

WAG (2004) Knowledge Economy Nexus: Role of Higher Education in Wales, Report of the Welsh Assembly Government's Higher Education and Economic Development Task and Finish Group, Cardiff.

WAG (2006) A Science Policy for Wales 2006: The Welsh Assembly Government's Strategic Vision for Sciences, Engineering and Technology, Welsh Assembly Government, Cardiff.

WAG (2007) One Wales: A progressive agenda for the government of Wales - An agreement between the Labour and Plaid Cymru Groups in the National Assembly, Welsh Assembly Government, Cardiff.

Warren L., Kitagawa F. and Eatough M. (2010) Developing the knowledge economy through university linkages: An exploration of RDA strategies through case studies of two English regions, International Journal of Entrepreneurship and Innovation. 11, 293-306.

Wellings P. (2008) Intellectual Property and Research Benefits, Lancaster University, Lancaster. 
Wink R. (2008) Gatekeepers and proximity in science-driven sectors in Europe and Asia: The case of human embryonic stem cell research, Regional Studies 42, 777-791.

Youtie J. and Shapira P. (2008) Building an innovation hub: A case study of the transformation of university roles in regional technological and economic development, Research Policy 37, 1188-1204. 
Figure 1: Governance, Regional Policy and University Knowledge Transfer LEVEL OF GOVERANCE POLICIES REGIONAL ECONOMY

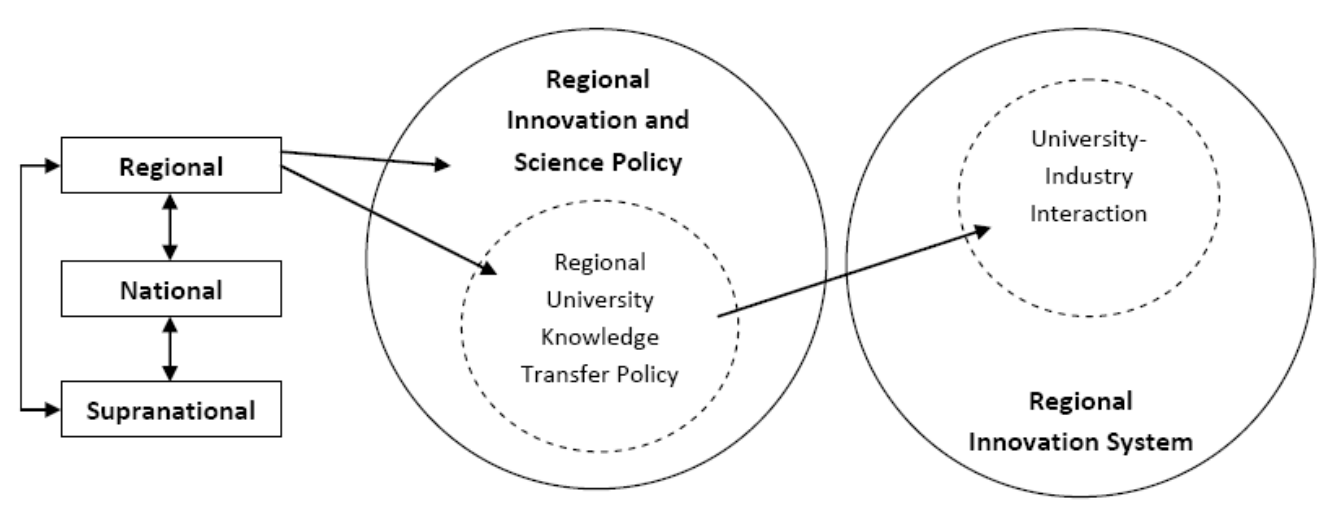


Table 1: Regional Higher Education Value Added 2005/06

\begin{tabular}{|l|c|c|c|}
\hline Region & $\begin{array}{c}\text { University and HEI } \\
\text { Value Added per } \\
\text { Full Time } \\
\text { Equivalent } \\
\text { Employee }(£)\end{array}$ & $\begin{array}{c}\text { Total Higher } \\
\text { Education } \\
\text { Value Added } \\
(£ 000 \text { s })\end{array}$ & $\begin{array}{c}\text { Contribution } \\
\text { to Regional } \\
\text { GVA }(\%)\end{array}$ \\
\hline Eastern England & 48,016 & 913,116 & 0.83 \\
\hline London & 47,371 & $2,558,439$ & 1.30 \\
\hline Northern Ireland & 42,488 & 269,142 & 1.02 \\
\hline West Midlands & 40,183 & 899,526 & 1.01 \\
\hline South East & 39,982 & $1,595,976$ & 0.90 \\
\hline Scotland & 39,539 & 969,618 & 1.07 \\
\hline North East & 38,624 & 511,966 & 1.32 \\
\hline Wales & 38,577 & 578,773 & 1.36 \\
\hline East Midlands & 37,409 & 736,900 & 0.99 \\
\hline North West & 37,181 & $1,174,995$ & 1.06 \\
\hline South West & 37,056 & 712,005 & 0.80 \\
\hline $\begin{array}{l}\text { Yorkshire and the } \\
\text { Humber }\end{array}$ & 36,991 & $1,004,509$ & 1.22 \\
\hline UK & 40,759 & $11,924,965$ & 1.03 \\
\hline
\end{tabular}


Table 2: Knowledge Transfer and Commercialisation (KTC) Income Received by Universities and HEIs per Employee (FTE)

\begin{tabular}{|c|c|c|c|}
\hline Region & $\begin{array}{c}\text { KTC Income per FTE } \\
\text { Employee }(£)\end{array}$ & $\begin{array}{c}\% \text { Change in KTC } \\
\text { Income } 2001 / 02- \\
2006 / 07\end{array}$ & $\begin{array}{c}\% \text { of KTC } \\
\text { Income } \\
\text { Generated } \\
\text { from each } \\
\text { Within Region }\end{array}$ \\
\hline Wales & 8,751 & 120.4 & 8.4 \\
\hline North East & 8,417 & 81.9 & 21.9 \\
\hline Eastern England & 8,175 & 68.0 & 23.3 \\
\hline London & 7,840 & 141.6 & 23.6 \\
\hline Scotland & 7,678 & 107.6 & 22.6 \\
\hline South East & 7,168 & 116.4 & 23.0 \\
\hline North West & 6,077 & 179.4 & 35.1 \\
\hline West Midlands & 5,955 & 162.4 & 24.4 \\
\hline East Midlands & 5,438 & 63.4 & 25.5 \\
\hline South West & 5,210 & 170.3 & 18.2 \\
\hline Yorkshire and the Humber & 4,874 & 144.6 & 29.8 \\
\hline Northern Ireland & 3,692 & 23.5 & 59.9 \\
\hline UK & 6,717 & 118.5 & \\
\hline
\end{tabular}

Source: Authors' calculations based on data from the annual Higher Education Business and Community Interaction Survey (http://www.hefce.ac.uk/econsoc/buscom/hebci/) 
Table 3: Knowledge Transfer and Commercialisation (KTC) Income Received by Universities and HEIs in Scotland

\begin{tabular}{|l|c|c|c|}
\hline & $\begin{array}{c}\text { KTC Income } \\
(£ 000 \mathrm{~s})\end{array}$ & $\begin{array}{c}\text { \% of All } \\
\text { Scotland } \\
\text { Total }\end{array}$ & $\begin{array}{c}\text { KTC Income } \\
\text { per FTE } \\
\text { Employee }(£)\end{array}$ \\
\hline University of Edinburgh & 41,619 & 17.9 & 6,543 \\
\hline University of Glasgow & 39,326 & 16.9 & 8,401 \\
\hline University of Strathclyde & 38,729 & 16.7 & 12,533 \\
\hline University of Aberdeen & 32,308 & 13.9 & 11,475 \\
\hline Heriot-Watt University & 22,959 & 9.9 & 15,232 \\
\hline University of Dundee & 19,819 & 8.5 & 6,479 \\
\hline University of St Andrews & 9,121 & 3.9 & 4,878 \\
\hline Glasgow Caledonian University & 8,308 & 3.6 & 4,863 \\
\hline Robert Gordon University & 7,140 & 3.1 & 5,468 \\
\hline University of Stirling & 5,813 & 2.5 & 3,723 \\
\hline University of Paisley & 3,117 & 1.3 & 2,993 \\
\hline $\begin{array}{l}\text { Queen Margaret University College } \\
\text { Edinburgh }\end{array}$ & 2,210 & 1.0 & 4,520 \\
\hline University of Abertay Dundee & 1,130 & 0.5 & 1,892 \\
\hline Glasgow School of Art & 552 & 0.2 & 1,718 \\
\hline $\begin{array}{l}\text { Royal Scottish Academy of Music and } \\
\text { Drama }\end{array}$ & 70 & 0.0 & 349 \\
\hline Scotland & 232,221 & 100.0 & \\
\hline Sour Auts & & & \\
\hline
\end{tabular}

Source: Authors' calculations based on data from the annual Higher Education Business and Community Interaction Survey (http://www.hefce.ac.uk/econsoc/buscom/hebci/) 
Table 4: Knowledge Transfer and Commercialisation (KTC) Income Received by Universities and HEIs in Wales

\begin{tabular}{|l|c|c|c|}
\hline & $\begin{array}{c}\text { KTC Income } \\
(£ 000 \mathrm{~s})\end{array}$ & $\begin{array}{c}\text { \% of All } \\
\text { Wales } \\
\text { Total }\end{array}$ & $\begin{array}{c}\text { KTC Income per } \\
\text { FTE Employee } \\
(£)\end{array}$ \\
\hline Cardiff University & 49,271 & 35.6 & 10,093 \\
\hline University of Wales Swansea & 49,224 & 35.6 & 25,203 \\
\hline University of Wales, Bangor & 11,545 & 8.3 & 7,242 \\
\hline University of Wales, Aberystwyth & 7,888 & 5.7 & 4,813 \\
\hline $\begin{array}{l}\text { North East Wales Institute of Higher } \\
\text { Education }\end{array}$ & 6,024 & 4.4 & 13,589 \\
\hline University of Wales Institute, Cardiff & 4,520 & 3.3 & 4,245 \\
\hline University of Glamorgan & 3,816 & 2.8 & 2,366 \\
\hline Swansea Institute of Higher Education & 1,949 & 1.4 & 4,119 \\
\hline University of Wales, Newport & 1,398 & 1.0 & 2,044 \\
\hline Royal Welsh College of Music and & 1,170 & 0.8 & 7,773 \\
\hline Drama & 950 & 0.7 & 3,620 \\
\hline Trinity College Carmarthen & 670 & 0.5 & 2,744 \\
\hline University of Wales, Lampeter & 138,425 & 100.0 & \\
\hline Wales & & & \\
\hline Source Aut can & & & \\
\hline
\end{tabular}

Source: Authors' calculations based on data from the annual Higher Education Business and Community Interaction Survey (http://www.hefce.ac.uk/econsoc/buscom/hebci/) 


\footnotetext{
1 'How does SFC help Scotland's colleges and universities exchange knowledge?' www.sfc.ac.uk accessed 20 November 2009.

2 'Horizon Fund for higher education institutions for academic year 2009-10' http://www.sfc.ac.uk/news_events_circulars/Circulars/2009/SFC14b09.aspx accessed 20 November 2009.

${ }^{3}$ The figure was based on the achievements of the Programme at that date and an initial investment of $£ 28$ million . http://www.academici.com/blog.aspx?bid=3069 accessed 14 July 2009.
} 